
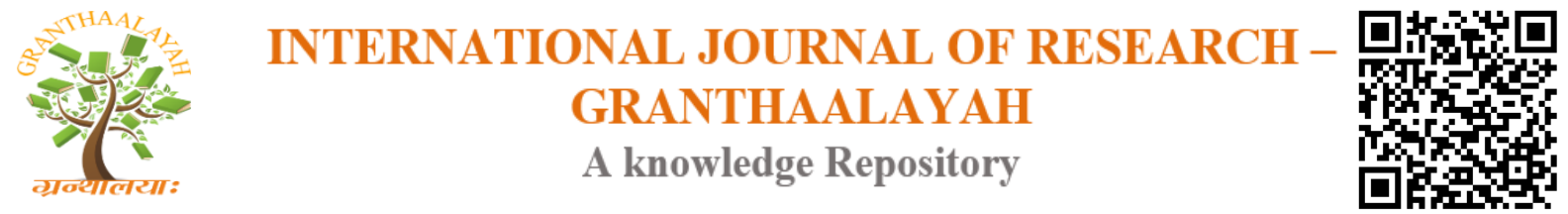

Management

\title{
GOODS AND SERVICES TAX - AN OVERVIEW
}

\author{
Dr. S. Bulomine Regi ${ }^{1}$, Dr. S. Anthony Rahul Golden ${ }^{2}$ \\ ${ }^{1}$ M.Com., M.Phil.,SET.,Ph.D., MBA(HR)., M.Sc(Psy)., M.P.Adm., Assistant Professor in \\ Business Administration (BBA), St. Xavier's College (Autonomous), Palayamkottai, India \\ ${ }^{2}$ M.Com., M.Phil., NET., MBA.,SET., NET., M.A., M.Sc. (Psy)., Ph.D., PGDBA., HOD of \\ Commerce \& Business Administration Loyola College of Arts \& Science, Mettala, Rasipuram, \\ Namakkal Dt- 636 202, India
}

\begin{abstract}
In the history of Indian taxation, GST is a new phenomenon. It can be said that it is the tax revolutions in India. It has crossed lots of stages in India tax system. It is not easy thing that implementing GST in India. Even though, in the world, it was first implemented in France in 1954 , it took these many years to come to India. In this study, the author clearly explains about the GST and its history.
\end{abstract}

Keywords: GST; India; Tax System; Implementation \& Consumer.

Cite This Article: Dr. S. Bulomine Regi, and Dr. S. Anthony Rahul Golden. (2017). "GOODS AND SERVICES TAX - AN OVERVIEW." International Journal of Research Granthaalayah, 5(7:SE), 1-6. https://doi.org/10.29121/granthaalayah.v5.i7(SE).2017.2034.

\section{Introduction}

\subsection{GST Meanings \& its Functioning}

GST is one indirect tax for the whole nation, which will make India one unified common market. GST is a single tax on the supply of goods and services, right from the manufacturer to the consumer. Credits of input taxes paid at each stage will be available in the subsequent stage of value addition, which makes GST essentially a tax only on value addition at each stage. The final consumer will thus bear only the GST charged by the last dealer in the supply chain, with set-off benefits at all the previous stages.

\subsection{Major chronological events that have led to the introduction of GST}

GST is being introduced in the country after a 13 year long journey since it was first discussed in the report of the Kelkar Task Force on indirect taxes. A brief chronology outlining the major milestones on the proposal for introduction of GST in India is as follows: 
1) In 2003, the Kelkar Task Force on indirect tax had suggested a comprehensive Goods and Services Tax (GST) based on VAT principle.

2) A proposal to introduce a National level Goods and Services Tax (GST) by April 1, 2010 was first mooted in the Budget Speech for the financial year 2006-07.

3) Since the proposal involved reform/ restructuring of not only indirect taxes levied by the Centre but also the States, the responsibility of preparing a Design and Road Map for the implementation of GST was assigned to the Empowered Committee of State Finance Ministers (EC).

4) Based on inputs from Govt of India and States, the EC released its First Discussion Paper on Goods and Services Tax in India in November, 2009.

5) In order to take the GST related work further, a Joint Working Group consisting of officers from Central as well as State Government was constituted in September, 2009.

6) In order to amend the Constitution to enable introduction of GST, the Constitution (115th Amendment) Bill was introduced in the Lok Sabha in March 2011. As per the prescribed procedure, the Bill was referred to the Standing Committee on Finance of the Parliament for examination and report.

7) Meanwhile, in pursuance of the decision taken in a meeting between the Union Finance Minister and the Empowered Committee of State Finance Ministers on 8th November, 2012, a 'Committee on GST Design', consisting of the officials of the Government of India, State Governments and the Empowered Committee was constituted.

8) This Committee did a detailed discussion on GST design including the Constitution (115th) Amendment Bill and submitted its report in January, 2013. Based on this Report, the EC recommended certain changes in the Constitution Amendment Bill in their meeting at Bhubaneswar in January 2013.

9) The Empowered Committee in the Bhubaneswar meeting also decided to constitute three committees of officers to discuss and report on various aspects of GST as follows:-

a) Committee on Place of Supply Rules and Revenue Neutral Rates;

b) Committee on dual control, threshold and exemptions;

c) Committee on IGST and GST on imports.

1) The Parliamentary Standing Committee submitted its Report in August, 2013 to the Lok Sabha. The recommendations of the Empowered Committee and the recommendations of the Parliamentary Standing Committee were examined in the Ministry in consultation with the Legislative Department. Most of the recommendations made by the Empowered Committee and the Parliamentary Standing Committee were accepted and the draft Amendment Bill was suitably revised.

2) The final draft Constitutional Amendment Bill incorporating the above stated changes were sent to the Empowered Committee for consideration in September 2013.

3) The EC once again made certain recommendations on the Bill after its meeting in Shillong in November 2013. Certain recommendations of the Empowered Committee were incorporated in the draft Constitution (115th Amendment) Bill. The revised draft was sent for consideration of the Empowered Committee in March, 2014.

4) The 115th Constitutional (Amendment) Bill, 2011, for the introduction of GST introduced in the Lok Sabha in March 2011 lapsed with the dissolution of the 15th Lok Sabha. 
5) In June 2014, the draft Constitution Amendment Bill was sent to the Empowered Committee after approval of the new Government.

6) Based on a broad consensus reached with the Empowered Committee on the contours of the Bill, the Cabinet on 17.12.2014 approved the proposal for introduction of a Bill in the Parliament for amending the Constitution of India to facilitate the introduction of Goods and Services Tax (GST) in the country. The Bill was introduced in the Lok Sabha on 19.12.2014, and was passed by the Lok Sabha on 06.05.2015. It was then referred to the Select Committee of Rajya Sabha, which submitted its report on 22.07.2015.

\subsection{Taxes at the Centre and State level are being subsumed into GST}

At the Central level, the following taxes are being subsumed:

1) Central Excise Duty,

2) Additional Excise Duty,

3) Service Tax,

4) Additional Customs Duty commonly known as Countervailing Duty, and

5) Special Additional Duty of Customs.

At the State level, the following taxes are being subsumed:

1) Subsuming of State Value Added Tax/Sales Tax,

2) Entertainment Tax (other than the tax levied by the local bodies), Central Sales Tax (levied by the Centre and collected by the States),

3) Octroi and Entry tax,

4) Purchase Tax,

5) Luxury tax, and

6) Taxes on lottery, betting and gambling.

\section{Benefits of GST}

The benefits of GST can be summarized as under:

\subsection{For Business and Industry}

- Easy compliance: A robust and comprehensive IT system would be the foundation of the GST regime in India. Therefore, all tax payer services such as registrations, returns, payments, etc. would be available to the taxpayers online, which would make compliance easy and transparent.

- Uniformity of tax rates and structures: GST will ensure that indirect tax rates and structures are common across the country, thereby increasing certainty and ease of doing business. In other words, GST would make doing business in the country tax neutral, irrespective of the choice of place of doing business.

- Removal of cascading: A system of seamless tax-credits throughout the value-chain, and across boundaries of States, would ensure that there is minimal cascading of taxes. This would reduce hidden costs of doing business.

- Improved competitiveness: Reduction in transaction costs of doing business would eventually lead to an improved competitiveness for the trade and industry. 
- Gain to manufacturers and exporters: The subsuming of major Central and State taxes in GST, complete and comprehensive set-off of input goods and services and phasing out of Central Sales Tax (CST) would reduce the cost of locally manufactured goods and services. This will increase the competitiveness of Indian goods and services in the international market and give boost to Indian exports. The uniformity in tax rates and procedures across the country will also go a long way in reducing the compliance cost.

\subsection{For Central and State Governments}

- Simple and easy to administer: Multiple indirect taxes at the Central and State levels are being replaced by GST. Backed with a robust end-to-end IT system, GST would be simpler and easier to administer than all other indirect taxes of the Centre and State levied so far.

- Better controls on leakage: GST will result in better tax compliance due to a robust IT infrastructure. Due to the seamless transfer of input tax credit from one stage to another in the chain of value addition, there is an in-built mechanism in the design of GST that would incentivize tax compliance by traders.

- Higher revenue efficiency: GST is expected to decrease the cost of collection of tax revenues of the Government, and will therefore, lead to higher revenue efficiency.

- For the consumer

- Single and transparent tax proportionate to the value of goods and services: Due to multiple indirect taxes being levied by the Centre and State, with incomplete or no input tax credits available at progressive stages of value addition, the cost of most goods and services in the country today are laden with many hidden taxes. Under GST, there would be only one tax from the manufacturer to the consumer, leading to transparency of taxes paid to the final consumer.

- Relief in overall tax burden: Because of efficiency gains and prevention of leakages, the overall tax burden on most commodities will come down, which will benefit consumers.

\section{GST Tax Slab}

The Goods and Services Tax (GST) has been one of the key things that has caught the attention of the market given its implications on earnings of companies. The government has kept a large number of items under $18 \%$ tax slab. The government categorised 1211 items under various tax slabs. Here is a low-down on the tax slab these items would attract:

\section{No tax $(0 \%)$ \\ Goods}

No tax will be imposed on items like Jute, fresh meat, fish chicken, eggs, milk, butter milk, curd, natural honey, fresh fruits and vegetables, flour, besan, bread, prasad, salt, bindi. Sindoor, stamps, judicial papers, printed books, newspapers, bangles, handloom, Bones and horn cores, bone grist, bone meal, etc.; hoof meal, horn meal, Cereal grains hulled, Palmyra jaggery, Salt all types, Kajal, Children's' picture, drawing or colouring books, Human hair.

Services

Hotels and lodges with tariff below Rs 1,000, Grandfathering service has been exempted under GST. Rough precious and semi-precious stones will attract GST rate of 0.25 per cent. 


\section{- $5 \%$}

\section{Goods}

Items such as fish fillet, Apparel below Rs 1000, packaged food items, footwear below Rs 500, cream, skimmed milk powder, branded paneer, frozen vegetables, coffee, tea, spices, pizza bread, rusk, sabudana, kerosene, coal, medicines, stent, lifeboats, Cashew nut, Cashew nut in shell, Raisin, Ice and snow, Bio gas, Insulin, Agarbatti, Kites, Postage or revenue stamps, stamppost marks, first-day covers.

\section{Services}

Transport services (Railways, air transport), small restaurants will be under the 5\% category because their main input is petroleum, which is outside GST ambit.

\section{$12 \%$ \\ Goods}

Apparel above Rs 1000, frozen meat products, butter, cheese, ghee, dry fruits in packaged form, animal fat, sausage, fruit juices, Bhutia, namkeen, Ayurvedic medicines, tooth powder, agarbatti, colouring Exercise books and note books, Spoons, forks, ladles, skimmers, cake servers, fish knives, tongs, Spectacles, corrective, Playing cards, chess board, carom board and other board games, like ludo.

\section{Services}

State-run lotteries, Non-AC hotels, business class air ticket, fertilisers, Work Contracts will fall under 12 per cent GST tax slab.

\section{- $18 \%$ \\ Goods}

Most items are under this tax slab which include footwear costing more than Rs 500, Trademarks, goodwill, software, Bidi Patta, Biscuits (All catogories), flavoured refined sugar, pasta, cornflakes, pastries and cakes, preserved vegetables, jams, sauces, soups, ice cream, instant food mixes, mineral water, tissues, envelopes, tampons, note books, steel products, printed circuits, camera, speakers and monitors, Kajal pencil sticks, Headgear and parts thereof, Aluminium foil, Weighing Machinery [other than electric or electronic weighing machinery], Printers [other than multifunction printers], Electrical Transformer, CCTV, Optical Fiber, Bamboo furniture, Swimming pools and padding pools, Curry paste; mayonnaise and salad dressings; mixed condiments and mixed seasonings.

\section{Services}

AC hotels that serve liquor, telecom services, IT services, branded garments and financial services will attract 18 per cent tax under GST, Room tariffs between Rs 2,500 and Rs 7,500, Restaurants inside five-star hotels.

\section{- $28 \%$}

\section{Goods}

Bidis, chewing gum, molasses, chocolate not containing cocoa, waffles and wafers coated with choclate, pan masala, aerated water, paint, deodorants, shaving creams, after shave, hair shampoo, dye, sunscreen, wallpaper, ceramic tiles, water heater, dishwasher, weighing machine, washing machine, ATM, vending machines, vacuum cleaner, shavers, hair clippers, automobiles, motorcycles, aircraft for personal use, will attract $28 \%$ tax - the highest under GST system. 


\section{Services}

Private-run lotteries authorised by the states, hotels with room tariffs above Rs 7,500, 5-star hotels, race club betting, cinema will attract tax 28 per cent tax slab under GST.

\section{Conclusion}

Thus, GST makes a single umbrella for taxation activities in India. In practice, there are lots of problems occur in charging or implementing GST tax system. If it is regularised and properly maintained the GST tax system, then it will be very much useful for the growth and development of our nation. It is our suggestion that some items should be changed to the lowest tax slab. Because, in India, majority of the population are still in poor and rural oriented. They cannot buy some products for their standard life. If it is reduced means, then they are able to buy and use them those products. Then we can move towards developed India.

\section{References}

[1] Golden, S. A. R. (2017). Recent Research in Social Sciences \& Humanities. EduPedia Publications (P) Ltd.

[2] Golden, S. A. R., \& Regi, S. B. (2013). Mobile commerce in modern business era. International Journal of Current Research and Academic Review, 1(4), 96-102.

[3] Golden, S. A. R., Regi, S. B., \& Franco, C. E. (2014). A study on Impact of Information Technology (IT) in Modern Banking Sector. Golden Research Thoughts, 3(11), 1.

[4] http://economictimes.indiatimes.com/articleshow/58743715.cms?utm_source=contentofinterest\& utm_medium=text\&utm_campaign=cppst

[5] Regi, S. B., \& Golden, S. A. R. (2014). Attitude of Rural People Towards Technology Inclusion In Banking Services At Tirunelveli District. IGJAE-Indo Global Journal Of Applied Management Science, 2 (2).

[6] Regi, S. B., \& Golden, S. A. R. (2014). Foreign Direct Investment-An Overview. IJARCSMS, 2 (2).

[7] Regi, S. B., \& Golden, S. A. R. (2014). Global Financial Crisis-Impact In India. Journal Of International Academic Research For Multidisciplinary, 2 (1), JIARM.

[8] Regi, S. B., Golden, S. A. R., \& Franco, C. E. (2014). Reforms In Insurance Sector In India-A Empirical Study. Review Of Research, 3 (9), 1, 5.

\footnotetext{
*Corresponding author.

E-mail address: drregi23@ gmail.com
} 